\title{
Morera y Gardel: «video clip» porteño
}

Jorge Gagliardi

Archivo de Historia del Parque de la Memoria

y Monumento a las Víctimas del Terrorismo de

Estado del GCBA.

\section{Resumen}

Eduardo Morera filmó is cortometrajes musicales con interpretación de Carlos Gardel y producción de Federico Valle en 1930, compilados con la denominación Asi cantaba Carlos Gardel. Suele clasificarse a estas obras Palabras clave: video clip, Eduardo Morera, Carlos Gardel, José Bohr, clasificación. como video clip, sin considerar la elaboración posterior de este género a partir de los años 70, que su circulación masiva comenzó en 198I por parte de la MTV y que no son producciones de la televisión sino de la cinematografía. Por otra parte, a partir de ese ordenamiento circula una disputa por quién es el hacedor pionero de ese tipo de texto cuatro décadas antes de la creación del género, entre Morera y Gardel, por un lado, y José Bohr por otro, quien, según lo proferido en su autobiografía, habría hecho una actuación musical en un cortometraje —actualmente desaparecido- con producción de la Paramount Pictures. Resulta pertinente, entonces, tratar algunas cuestiones sobre la producción y la recepción de 
estos cortometrajes, tendientes a incentivar la reflexión acerca de su clasificación social.

\section{Abstract \\ Morena y Gardel: the "video clip" porteño (from Buenos Aires)}

In 1930 Eduardo Morera filmed is musical short films starring Carlos Gardel and produced by Federico Valle; they were compiled under the denomination Asi cantaba Carlos Gardel (Thus Sang Carlos Gardel). These works are usually Keywords:

video clip, Eduardo Morera, Carlos Gardel, José Bohr, classification. classified as video clips, without considering that this genre was elaborated in the 70's, that its massive circulation started in 198I by the MTV, and that they are not television productions but rather film productions. Moreover, this created a dispute over who the pioneer maker of such text is, four decades before the creation of the genre. Is it Morera and Gardel? Or is it José Bohr? Who, according to his autobiography, did a musical performance in a short film production — currently missing — co-produced by Paramount Pictures. It is pertinent, therefore, to address some questions about the production and reception of these short films; questions aimed to encourage reflection about their social classification.

\section{Clasificación y memoria}

Eduardo Morera dirigió Is cortometrajes musicales a partir de 15 canciones interpretadas por Carlos Gardel en un estudio de Federico Valle en Buenos Aires entre el 23 de octubre y el 3 de noviembre de
1930, de los cuales io (Viejo smoking, Rosa de otoño, Mano a mano, Yira yira, Tengo miedo, Padrino pelao, Canchero, Enfundá la mandolina, Añoranzas y Carretero) fueron estrenados ${ }^{1}$ y hoy en día están preservados en un archivo

1. El primer cortometraje (Viejo smoking) se estrenó el 3 de mayo de 1931 en el cine Astral previo a la proyección de City Lights (Luces de la ciudad) de Charles Chaplin.Fuente: Instituto Nacional de Cine y Artes Audiovisuales: Biblioteca y Centro de Documentación y Archivo, Buenos Aires, Argentina [consultado 1 julio 2014]. 